\title{
CYTOTOXIC AND ANTIMICROBIAL ACTIVITIES OF TWO NEW TRITERPENOIDS FROM THE PEELS OF LOCAL EGYPTIAN MALUS DOMESTICA L.
}

\author{
Y. A. SELIM ${ }^{1, \dagger} A N D$ K. E. LITINAS \\ ${ }^{1}$ Faculty of Specific Education, Zagazig University, Egypt \\ ${ }^{2}$ Faculty of science, Aristotle University of Thessaloniki, Thessaloniki, Greece.
}

\begin{abstract}
The local Egyptian peels of Malus domestica was extracted successively with absolute ethanol and partitioned sequentially with n-hexane, chloroform and methanol. Friedelin (1) was isolated from the n-hexane fraction, and betulinic acid (2) from the chloroform fraction. The new compounds $2 \alpha-h y d o r x y-3$-oxolup-12(13), 20(29)-dien-27, 28-dioic acid (3) and 2 $\alpha$, 27-dihydorxy-3-oxo-lup-12(13), 20(29)-dien-28-oic acid (4) were isolated from the methanol fraction and elucidated by spectroscopic data interpretation. Friedelin (I) and betulinic acid (2) are known compounds that are newly identified from peels of Malus domestica. The compounds $3 \& 4$ are appreciably active against Gram-positive species and Gram-negative species, associated with week anti-fungal activity. Among them, compounds (3) and (4) exhibited cytotoxic activity against the breast carcinoma and human colon carcinoma cells, with (4) being slightly most potent toward to the breast carcinoma while, (3) being slightly most potent toward to the human colon carcinoma cells .
\end{abstract}

Key words: Malus domestica; triterpenoids; plant extraction; betulinic acid; Cytotoxicity.

\section{INTRODUCTION}

Malus domestica a medium sized tree belonging to Rosaceae and deciduous, well known by the whole world for its delicious and nutritious fruits which are being grown in temperate region of the world. ${ }^{1}$ About 25 to 47 different Malus species are known, among which around seven species are taxonomically close to $M$. domestica ${ }^{2,3}$ It exhibit efficient antioxidant property owing to the presence of its phytoconstituents which are known for their anti inflammatory, antiviral and antimicrobial properties. ${ }^{4,5}$ The apple fruit cuticle is $70-80 \%$ cutine, which is an insoluble biopolymer consisting of polyphenol esters of long-chain hydroxy-fatty acids, structurally merged with waxy material (20-30\%), free fatty acids, phenols and small amounts of pectin, cellulose with strong antioxidant properties. ${ }^{6,7}$ These phenolic compounds residing in apple pomace are provides beneficial diet for human health ${ }^{8}$ Apples ranked second for total concentration for phenolic compounds and having highest portion of free phenolic when compared to other fruits. ${ }^{9,10}$ As it has health-beneficial constituents such as sugars and vitamins compounds, which are responsible for curing cancer, cardiovascular disease, asthma, and diabetes. ${ }^{11}$ Egyptian apple pomace contained considerable amounts of gallic acid, vanillic acid and flavonoids. ${ }^{12} 2 \alpha$ - hydroxyursolic acid, $2 \alpha$-hydroxy-3 $\beta-\{[(2 \mathrm{E})-3$-phenyl-1-oxo2 -propenyl]oxy\}olean-12-en-28-oic acid, and $\beta$-trans-p-coumaroyloxy-2 $\alpha$ hydroxyolean-12-en-28-oic acid were isolated from peels of Malus domestica and showed higher antiproliferative activity toward HepG2 cancer cells. ${ }^{13}$ Apples are among the fruit most consumed worldwide and anti-tumoral effects from apples are correlated with the fruit peel. ${ }^{14}$ Separation of these acids from vegetal matrices usually employs organic solvents, such as ethanol, chloroform and $n$-hexane, however, efficient processes to separate these acids from apple peels must overcome some physical and chemical barriers that ordinarily hamper the extraction process such as the poor solubility of the triterpene acids in environmentally friendly solvents. ${ }^{15}$ In addition since there have been no previous reports on the identification of bio active lupane triterpenoids from the peels of the plant, we believe the present study was a trial to investigate and isolate more effective bioactive lupane triterpenes compounds from the peels of Egyptian apple and study the antimicrobial and cytotoxic effect.

\section{EXPERIMENTAL}

\subsection{General Experimental Procedures}

Melting points were measured on a Yanaco micro melting point apparatus and are uncorrected. Optical rotations were measured on a Perkin-Elmer 241 polar meter. ${ }^{1} \mathrm{H}$ and ${ }^{13} \mathrm{C}$ NMR spectra were measured on a JEOL JNMX400 spectrometer $(400 \mathrm{MHz})$ with TMS as an internal standard. EIMS were recorded on a Micromass TRIO-2000 GC/MS spectrometer, and HREIMS were recorded on a Finnigan/ Thermo Quest MAT mass spectrometer. Preparative TLC was performed on percolated silica gel 60 F254 plates (1 mm, Merck), using solvent system petroleum ether- EtOAc (3:1), detection with $\mathrm{I}_{2}$ spray. IR Spectra: Jusco A-302 spectrophotometer; $\mathrm{m}_{\mathrm{ix}}$ in $\mathrm{cm}^{-1}$.

\subsection{Plant Material}

The dried air underground peels of local Egyptian Malus domestica were collected in the summer March 2009 from local markets in Zagazig City, Sharkia Government, Egypt. Prof Dr. F. Gamal authenticated it; prof. of the aromatic and medicinal plants, Botany Department, Faculty of Science, Zagazig University, Zagazig, Egypt and a voucher specimen was deposited at the same institute in Egypt (SM1178).

2.3. Extraction and Isolation

The dried peels $(0.750 \mathrm{~kg})$ of Malus domestica were extracted three times with absolute EtOH for $72 \mathrm{hr}$. at room temperature to give an extract $(11.2 \mathrm{~g})$. The residue was suspended in $\mathrm{H}_{2} \mathrm{O}$ and partitioned sequentially with $n$-hexane, $\mathrm{CH}_{2} \mathrm{Cl}_{2}$ and $\mathrm{MeOH}$. The $\mathrm{MeOH}$ fraction after removal of the solvent by evaporation, ( $3.8 \mathrm{~g}$ ) was chromatographed using silica gel column chromatography, with gradient mixtures of $n$-hexane and EtOAc, of increasing polarity as solvents. to give two new triterpenoid compounds $2 \alpha$-hydorxy-3ketolup-12(13),20(29)-dien-27,28 -dioic acid 3 (1.6 g) and 2a,27- dihydorxy3-ketolup-12(13), 20(29)-dien-28-oic acid 4 (1.1 g) with $n$-hexane - EtOAc (1:1). Triterpenoid Compound $\mathbf{1}(0.41 \mathrm{~g})$ was obtained from $n$-hexane Fraction $1(2.2 \mathrm{~g})$ with silica gel column chromatography using mixtures of $n$-hexane -EtOAc. Fraction $2(1.94 \mathrm{~g})$ was chromatographed by silica gel column chromatography and eluted with $\mathrm{CH}_{2} \mathrm{Cl}_{2}-\mathrm{MeOH}(2: 1)$ to give betulinic acid 2 $(0.40 \mathrm{~g})$. (Figure 1).
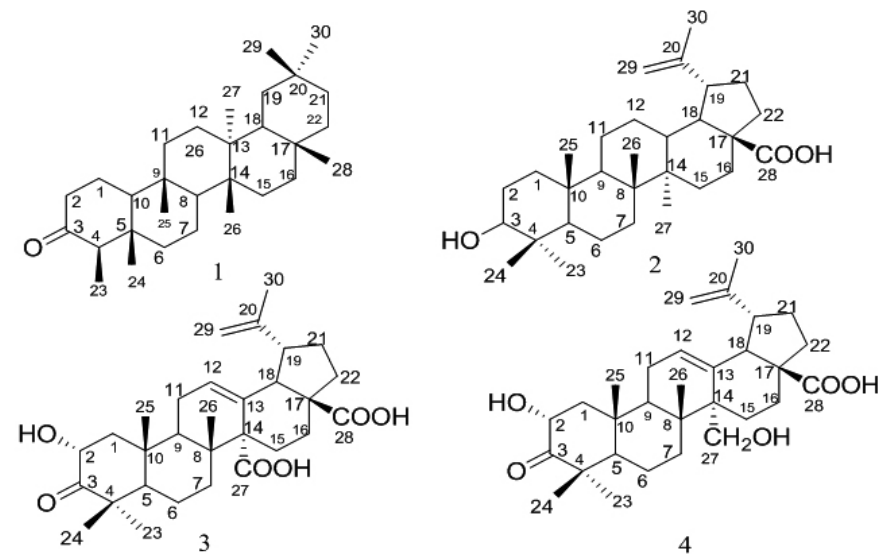

Figure 1. The structures of compounds 1-4.

2.4. 2a-hydorxy-3-oxo-lup-12(13),20(29)-dien-27,28-dioic acid (3)

Colourless needles (acetone), mp 218-220 ${ }^{\circ} \mathrm{C}$; $[\mathrm{R}]^{\mathrm{D}}+21^{\circ}\left(\mathrm{CHCl}_{3}\right)$; IR (KBr) $\lambda$ 3500-2750 (for more than one $\mathrm{COOH}$ ), 2947, 2866,1750 (ketone group), 1737,1730 (carbonyl carboxyl group), $1460,1377,1244 \mathrm{~cm}^{-1}$; ${ }^{1} \mathrm{H}$ and 
${ }^{13} \mathrm{C}$ NMR, see (Table1); EIMS m/z $498[\mathrm{M}]+(0.1), 470\left[\mathrm{M}-\mathrm{H}_{2} \mathrm{O}\right]^{+}(0.4), 467$ $\left[\mathrm{M}-\mathrm{CH}_{2} \mathrm{OH}\right]^{+}(1.8), 453[\mathrm{M}-\mathrm{COOH}]^{+}$(11.3), 467 (10.3), 262 (9.4), 236 (18.4), 249 (51.6), 236(100), 118 (13.4); HREIMS $m / z 498.3020$ (calcd for $\left.\mathrm{C}_{30} \mathrm{H}_{42} \mathrm{O}_{6}, 498.6510\right)$.

2.5. 20,27-dihydorxy-3-oxo-lup-12(13),20(29)-dien-28-oic acid (4)

Colourless needles (acetone), mp $214-216{ }^{\circ} \mathrm{C}$; $[\mathrm{R}]^{\mathrm{D}}+8.1^{\circ}\left(\mathrm{CHCl}_{3}\right)$; IR $(\mathrm{KBr}) \lambda_{\max } 3500(\mathrm{COOH}), 2970,1745$ (ketone group), 1735 (carbonyl carboxyl group), $1465,1388,1370,1244 \mathrm{~cm}^{-1} ;{ }^{1} \mathrm{H}$ and ${ }^{13} \mathrm{C}$ NMR, see (Table1); EIMS $m / z 484[\mathrm{M}]^{+}(6.1), 466\left[\mathrm{M}-\mathrm{H}_{2} \mathrm{O}\right]^{+}(0.4),\left[\mathrm{M}-\mathrm{CH}_{2} \mathrm{OH}\right]^{+} 483$ (5.6), [M $2 \mathrm{COOH}]^{+} 394$ (18.3), 249 (11.2), 176 (100), 159 (10.6), 118(51.4). HREIMS $\mathrm{m} / z 484.3211$ (calcd for $\mathrm{C}_{30} \mathrm{H}_{44} \mathrm{O}_{5}, 484.6701$ ).

2.6. Antimicrobial Assays

The antimicrobial activities of $\mathbf{3 , 4}$ were evaluated against Gram-positive Staphylococcus.. aureus (ATCC26003) , Staphylococcus. pneumonia (ATCC49619), and Micrococcus luteus (ATCC10240) and Gram-negative Escherichia coli (ATCC44104) and Pseudomonas aeruginosa (ATCC10223) and Fungi Candida albicans (ATCC11006) and Candida parapsilosis (ATCC22019), using loop of bacterium from stock agar slant cultures was cultured in nutrient broth overnight $\left(\right.$ at $37^{\circ} \mathrm{C}$ ) and spread with a dry sterile cotton swap onto triplicate set of Petri plates each containing $25 \mathrm{~mL}$ of sterile solidified Mueller Hinton agar medium. Twenty four hours post incubation (at $37^{\circ} \mathrm{C}$ ), zones (DIZs) induced by extract-loaded discs $(12.5-50 \mu \mathrm{g} / \mathrm{disc})$ were measured and approximated. The minimal inhibitory concentrations (MICs) values of both plant extracts were assessed as shown in Table 2. The MIC was defined as the lowest concentration $(\mu \mathrm{g} / \mathrm{mL})$ of the tested material that completely inhibited the growth of the test organism. ${ }^{16}$ As shown in (Table 2).

2.7. Cytotoxic Activity Assays

Authentic cultures of CRL-2351 (Human breast carcinoma) and HCT-15 (Human colon carcinoma) cells were obtained from Thessaloniki, Institute of Medical Science, Greece. cells were suspended in RPMI 1640 medium supplemented with $10 \%$ fetal calf serum, $1 \%$ antibiotic antimycotic mixture $(10.000 \mathrm{U} / \mathrm{ml} \mathrm{K}$-penicillin, $10.000 \mu \mathrm{g} / \mathrm{ml}$ streptomycin sulphate and $25 \mu \mathrm{g} / \mathrm{ml}$ Amphotericin B) and 1\% L glutamine (all purchased from Lonza, Belgium). The cytotoxicity against CRL-2351 and CRT-15 cells were tested according to the SRB (Sulforhodamine B) assay using MTT (3-(4, 5-dimethylthiazol2-yl) - 2, 5-diphenyltetrazolium bromide).$^{17}$ Adriamycin ${ }^{\circledR}$ (Doxorubicin) $10 \mathrm{mg}$ vials (Pharmacia, Sweden) was used as the reference drug. cells were plated in 96-multiwell plates $(5 \times 104-105$ cells/well in a fresh media) for 24 $\mathrm{h}$ before treatment with the tested sample to allow attachment of cells to the wall of the plate. Then, $200 \mu \mathrm{l}$ aliquot of serial dilution with DMSO (100\%) of alcoholic extract and isolated compounds $(5.0,12.5,25,50 \mu \mathrm{g} / \mathrm{ml})$ were added and the plates were incubated for 24,48 and $72 \mathrm{~h}$ at $37^{\circ} \mathrm{C}$ in a humidified incubator containing $5 \% \mathrm{CO}_{2}$ in air. Control cells were treated with vehicle alone. Four wells were prepared for each individual dose. Following 24, 48 and $72 \mathrm{~h}$ treatment, cells were fixed, washed and stained with Sulforhodamine B stain (Sigma, USA). Colour intensity was measured in an ELISA reader spectrophotometer (Tecan Group Ltd.-Sunrise, Germany).

\section{RESULTS AND DISCUSSION}

\subsection{Structure elucidation}

The ethanolic extract of the dried peels of local Malus domestica was divided into $n$-hexane- methylene chloride and methanol-soluble fractions. The $n$-hexane fraction was chromatographed and purified by repeated Silica gel column chromatography to give compounds 1 (Figure 1). Analogous purification procedures of the methylene chloride fraction gave compound 2 (Figure 1). The known compounds $\mathbf{1}$ was identified as friedelin. The comparison of the NMR spectral features of the existing literature. ${ }^{18,19}$ suggests that the isolated compound is a pentacyclic triterpene. Therefore, the structure of the isolated compound (Figure 1) was assigned based on the chemical shifts obtained from 1D, 2D ( ${ }^{1} \mathrm{H}$ and ${ }^{13} \mathrm{C}$ NMR) which revealed the presence of 30 carbons typical of friedelane skeleton..$^{18-20}$ To the best of our knowledge, this is the first report of the presence of friedelin in peels M. domestica. Compound $\mathbf{2}$ was identified as betulinic acid respectively, by comparison of their NMR, MS and physical data with those described in the literature. ${ }^{21}$

Compound 3 was obtained as colourless needles, mp $218-220{ }^{\circ} \mathrm{C}$ and a positive Zimmermann test for 3-keton-triterpenes. ${ }^{22}$ The molecular formula, $\mathrm{C}_{30} \mathrm{H}_{42} \mathrm{O}_{6}$, was determined by HREIMS and confirmed by ${ }^{13} \mathrm{C}$ NMR analyses. The ${ }^{12} \mathrm{C}$ NMR spectrum of $\mathbf{3}$ revealed 30 carbon signals, which were ascribed to five methyl, nine methylene, six methine, seven quaternary carbons, and three carbonyl carbons (Table 1). The ${ }^{1} \mathrm{H}$ NMR spectrum of $\mathbf{3}$ showed an olefinic proton signal $\left(\delta_{H} 5.88, \mathrm{dd}, J=13.5,7.4 \mathrm{~Hz}\right)$, a secondary alcohol group $\left(\delta_{H} 3.8\right.$, br s) and five tertiary methyl groups $\left[\delta_{H} 1.05,1.25,1.04,1.14\right.$ and 1.81 (each
$3 \mathrm{H}, \mathrm{s})]$. See Table 1 . The location of the keto group at C-3 was confirmed by the HMBC correlations of $\mathrm{H}_{3}-24(\delta 1.25) / \mathrm{H}_{3}-23(\delta 1.05)$ with $\mathrm{C}-3(\delta c 216.6)$ (Figure 2). From the ${ }^{13} \mathrm{C}$ NMR spectra, an isopropenyl group $\mathrm{H}_{3}-30\left(\delta_{H} 1.87\right.$, s), $\mathrm{H}_{-}-29\left(\delta_{H} 5.08\right), \mathrm{H}_{\mathrm{b}}-29\left(\delta_{H} 4.76\right) ; \mathrm{C}-30\left(\delta_{c} 29.3\right), \mathrm{C}-29\left(\delta_{c} 110.2\right)$, and $\mathrm{C}-20$ $\left(\delta_{c} 142.1\right)$. Assignments of the ${ }^{1} \mathrm{H}$ and ${ }^{13} \mathrm{C}$ signals by $2 \mathrm{D}$ NMR spectra revealed that 3 was an analogue of lup-12- en-28-oic acid. ${ }^{23}$ The remaining Three signals were characteristic for the oxygenated carbons, C-3 $\left(\delta_{c} 216.6\right), \mathrm{C}-27\left(\delta_{c} 181.2\right)$, and C-28 $\left(\delta_{c}\right.$ 175.2).

Table 1. ${ }^{1} \mathrm{H}$ and ${ }^{13} \mathrm{C}$ NMR Spectroscopic Data for Compounds $\mathbf{3}$ and $\mathbf{4}$

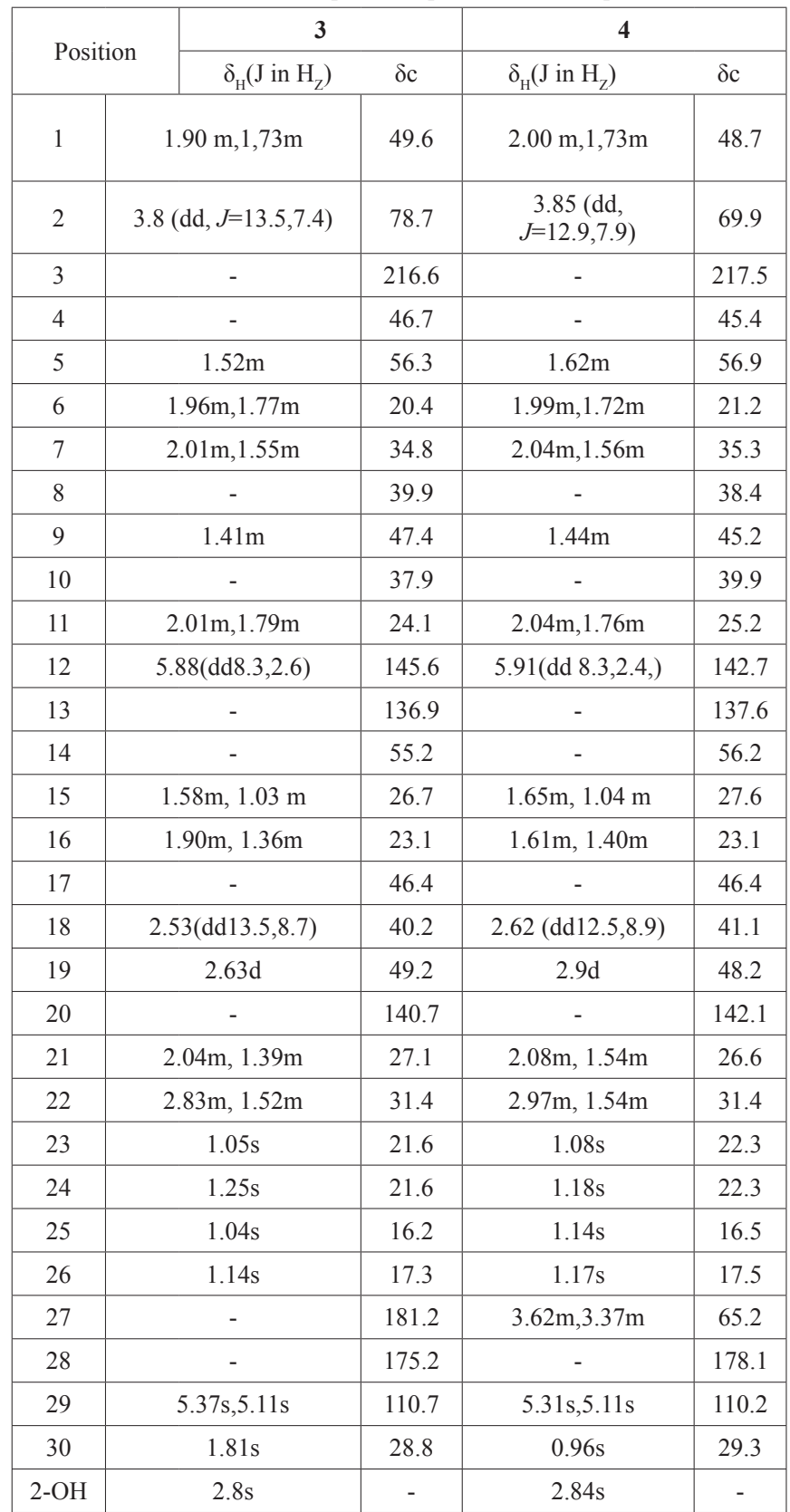

The ${ }^{13} \mathrm{C}$ NMR analyses showed no resonance for any oxygenated methylene and displayed instead to carbonyl signals at $\delta \quad 181.2$ and $\delta 175.2$ indicated a carbon atom bearing two oxygen, were assigned to a carboxyl groups at the C-27 and C-28 positions respectively. Based on the HMBC spectrum there were long-range correlations between protons and carbons: $\mathrm{H}-18 / \mathrm{C}-13(\delta$, $136.9), \mathrm{C}-17(\delta, 46.4)$ and carboxyl group $\mathrm{C}-28(\delta, 175.2) ; \mathrm{H}_{z}-15\left(\delta_{H} 1.58\right)$, $\mathrm{H}_{\mathrm{b}}-15\left(\delta_{H} 1.03 \mathrm{~m}\right), \mathrm{H}_{\mathrm{a}}-16\left(\delta_{H} 1.90\right)$ and $\mathrm{H}_{\mathrm{b}}-16\left(\delta_{H} 1.36\right) / \mathrm{C}-27\left(\delta_{c} 181.2\right)$ indicated, the ketone carbonyl groups must be either at position C-27 and C-28. (Figure 2) ${ }^{24}$ In addition, the carbon at C-14 signal resonated further downfield 
$\left(\delta_{c} 60.2\right)$, these data indicated the presence of an additional carboxyl group attached to C-14 of compound 3. MS fragmentations at $\mathrm{m} / \mathrm{z} 277$ and $\mathrm{m} / \mathrm{z} 267$ indicated the $\mathrm{C}-28$ of carboxyl group attached at C-14 (Figure 3). The larger coupling constant of $\mathrm{H}-18\left(\delta_{\mathrm{H}} 2.53\right.$, dd, $\left.J=13.5,8.7 \mathrm{~Hz}\right)$ and $\mathrm{H}-12\left(\delta_{H} 5.88\right.$, dd, $J=9.6,4.3 \mathrm{~Hz}$ ) showed the equatorial and axial orientations of protons at C-18 and $\mathrm{C}-12$, respectively. In addition, the absence of the correlation between $\mathrm{H}-12$ and $\mathrm{H}-18$ further confirmed the orientations of protons at C-18 and C-12 as above mentioned. The presence of a trisubstituted olefin between $\mathrm{C}-12$ and $\mathrm{C}-13$ was revealed by the HMBC correlations observed for $\mathrm{H}_{2}-11 / \mathrm{C}-12$ $(\delta, 145.6)$ and $\mathrm{C}-13(\delta, 136.9) ; \mathrm{H}-18 / \mathrm{C}-13(\delta, 136.9) \cdot{ }^{13} \mathrm{C}$ NMR showed that one downfield quaternary carbon signal at $\delta, 216.6(\mathrm{C}-3)$ and one downfield methine carbon signal at $68.7(\mathrm{C}-2)$ showed the presence of ketonic and one hydroxyl functionality in the molecule..$^{25}$ The location of the ketone group at C-3 was confirmed by the HMBC correlations of $\mathrm{H}_{3}-23\left(\delta_{H} 1.05\right) / \mathrm{H}_{3}-24\left(\delta_{H}\right.$ $1.25)$ with $\mathrm{C}-3\left(\delta_{c} 216.6\right)$ and of $\mathrm{H}-2\left(\delta_{H} 3.8\right)$ with $\mathrm{C}-3\left(\delta_{c} 216.6\right)$. The coupling of $\mathrm{H}-2\left(\delta_{H} 3.8\right)$ with $\mathrm{C}-24\left(\delta_{\mathrm{c}} 216.6\right)$, indicated, that the hydroxyl group should be positioned at $\mathrm{C}-2 .{ }^{26}$ The relative configuration of the $\mathrm{OH}$ group at $\mathrm{C}-2$ was assigned as $\alpha$ on the basis of ${ }^{1} \mathrm{H}$ NMR spectrum showed a proton signal of $\mathrm{H}-2$ $\left(\delta_{H} 3.80, \mathrm{dd}, J=13.5,7.4 \mathrm{~Hz}\right)$ and low-frequency chemical shifts of C-1 $\left(\delta_{c} 48.7\right)$ and $\mathrm{C}-2\left(\delta_{c} 69.9\right)$. As well as correlation between $\mathrm{H}-2\left(\delta_{H} 3.80\right)$ and $\mathrm{H}_{2}-1\left(\delta_{H}\right.$ 1.9 and 1.73) (Figure 2). ${ }^{27}$ The presence of the double bond at $\mathrm{C}-12$ confirmed by the chemical shifts of $\mathrm{C}-12\left(\delta_{c} 145.6\right)$ and $\mathrm{C}-13\left(\delta_{c} 136.9\right)$, characteristic of a $\Delta^{12}$ skeleton. ${ }^{28}$ Therefore, compound 3 was assigned $2 \alpha$-hydorxy-3-oxolup-12(13), 20 (29)-dien-27,28-dioic acid.
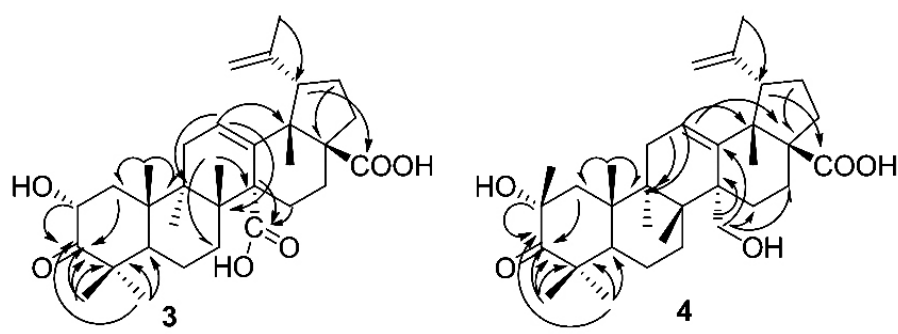

Figure 2. Key HMBC correlation of compounds 3-4
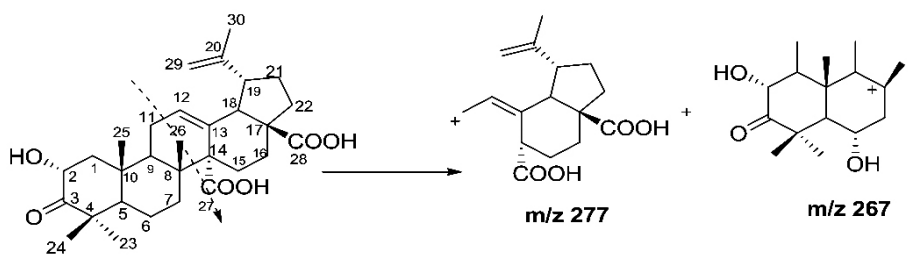

Figure 3. Mass fragmentation patterns of $\mathbf{3}$

Compound 4 was obtained as colorless needles, mp $214-216{ }^{\circ} \mathrm{C}$. The molecular formula, $\mathrm{C}_{30} \mathrm{H}_{44} \mathrm{O}_{5}$, was determined by HREIMS ion peak at $\mathrm{m} / \mathrm{z} 484.3211[\mathrm{M}]^{+}$, fourteen mass units less than that of $\mathbf{3}$ and suggesting replacement of the carbonyl group of $\mathbf{3}$ by an $\mathrm{CH}_{2}$ group in $\mathbf{4}$, this was confirmed by the lack of one carbonyl absorption in the IR spectrum and ${ }^{13} \mathrm{C}$ NMR analyses. The ${ }^{1} \mathrm{H}$ and ${ }^{13} \mathrm{C}$ NMR data were closely related to those of $\mathbf{3}$, alcohol group was located at the $\mathrm{C}-27$, which suggested 4indicated to be an analogue of 3-epibetulinic acid (Table 1). In the HMBC spectrum (Figure 2), the primary alcohol group resonating at $\delta, 3.62$ and 3.37 was correlated with $\mathrm{C}-8, \mathrm{C}-13$, and $\mathrm{C}-14$, indicating that the primary alcohol group was located at the $\mathrm{C}-27$ position. ${ }^{24}$ The presence of a trisubstituted olefin between $\mathrm{C}-12$ and $\mathrm{C}-13$ was revealed by the HMBC correlations observed for $\mathrm{H}_{2}-11 / \mathrm{C}-12(\delta$, 125.6) and $\mathrm{C}-13\left(\delta_{c}, 136.9\right) ; \mathrm{H}-18$ and $\mathrm{H}_{2}-27 / \mathrm{C}-13\left(\delta_{c}, 136.9\right)$. Therefore, the structure of $\mathbf{4}$ was represented by $2 \alpha, 27$-dihydorxy-3-oxo-lup-12(13), 20(29) - dien-28-oic acid.

3. 2. Antimicrobial activity

Both compounds $\mathbf{3}$ and $\mathbf{4}$ showed good inhibitory effects against Grampositive and against Gram-negative bacterial species tested with no antagonistic effects against fungi species (Table 2). The MICs values of $\mathbf{3} \boldsymbol{\&} \mathbf{4}$ were on the range 18 and $37 \mu \mathrm{g} / \mathrm{ml}$ on Gram-positive and Gram-negative whereas both compounds exhibited very weak fungal activity against with very high values ${ }^{16}$ (Table 2).
Table 2. Antimicrobial values \& MIC of compounds 3 and 4

\begin{tabular}{|c|c|c|c|c|}
\hline \multirow{2}{*}{ Test organisms } & \multicolumn{2}{|c|}{$\begin{array}{c}\text { MIC( } \mu \mathrm{g} / \\
\text { ML }\end{array}$} & $\begin{array}{c}\text { Tetracycline } \\
25 \mu \mathrm{g} / \mathrm{disc}\end{array}$ & $\begin{array}{c}\text { Penicillin } 25 \mu \mathrm{g} / \\
\text { disc }\end{array}$ \\
\cline { 2 - 3 } $\mathbf{3}$ & $\mathbf{4}$ & & \\
\hline Gram +Ve & & & & 26.0 \\
\hline $\begin{array}{c}\text { Staphylococcus. } \\
\text { aureus }\end{array}$ & 23.0 & 27.0 & 32.0 & 29.0 \\
\hline $\begin{array}{c}\text { Streptococcus } \\
\text { Pneumonia }\end{array}$ & 29.0 & 25.0 & 28.0 & 28.0 \\
\hline Micrococcus luteus & 28.0 & 18.0 & 31.0 & 29.0 \\
\hline $\begin{array}{c}\text { Gram-Ve } \\
\text { Escherichia coli }\end{array}$ & 37.0 & 18.0 & 28.0 & 32.0 \\
\hline $\begin{array}{c}\text { Pseudomonas } \\
\text { aeruinose }\end{array}$ & 29.0 & 29.0 & 28.0 & 21.0 \\
\hline $\begin{array}{c}\text { Fungi } \\
\text { Candida albicans }\end{array}$ & 3.0 & 8.0 & 25.0 & 23.0 \\
\hline $\begin{array}{c}\text { Candida } \\
\text { parapsilosis }\end{array}$ & 8.0 & 7.0 & 25.0 & \\
\hline
\end{tabular}

\section{3. Cytotoxic activity}

The results of potential cytotoxic activity of compounds $\mathbf{3}$ and $\mathbf{4}$ against the CRL-2351 (Breast cancer) and HCT-15 (Human colon carcinoma) cells obtained from the present study with doxorubicin as a positive control (Table 3) demonstrated that the two new triterpenoids compounds 3 and 4 are moderately cytotoxic. The results found that the incubation of CRL-2351 cell with triterpenoid compounds $3 \& 4$ at all concentrations $(5-50 \mu \mathrm{g} / \mathrm{ml})$ for $24 \mathrm{~h}$ reduced the viability of these cells. The dead cells which, were treated by compound 4 were increased by increasing the concentration (Table 3 ). The highest CRL-2351 dead cell (\%) was recorded by $2 \alpha, 27$ - dihydorxy-3ketolup-12 (13), 20(29)-dien-28-oic acid 4 ( $\left.\mathrm{IC}_{50} 3.43 \mu \mathrm{g} / \mathrm{ml}\right)$ for concentration of $50 \mu \mathrm{g} / \mathrm{ml}$ as comparison with doxorubicin, while it was $\left(\mathrm{IC}_{50} 3.45 \mu \mathrm{g} / \mathrm{ml}\right)$ for $50 \mu \mathrm{g} / \mathrm{ml}$ concentration of $2 \alpha$-hydorxy-3-ketolup-12 (13), 20(29)-dien27,2 dioic acid 3 . It must be noticed that there were no significant difference in dead cells $(5,12.5$ and $25 \mu \mathrm{g} / \mathrm{ml})$ of compound 4 (Table 3$)$. Also, no significant different in dead cells (\%) of CRL- cell line between compound 3 at (5 and $12.5 \mu \mathrm{g} / \mathrm{ml}$ ) concentration and compound 4 at the same concentration. ${ }^{17}$ It appeared that the in vitro cytotoxicity of compound 3 against HCT-15 was more potent $\left(\mathrm{IC}_{50} 3.12 \mu \mathrm{g} / \mathrm{ml}\right)$ than compound $\mathbf{4}\left(\mathrm{IC}_{50}=3.98 \mu \mathrm{g} / \mathrm{ml}\right)$. The cytotoxic activity may be due to the presence of terpenoids present in the peels of Malus domestica. Regarding these results, it is interesting to notice that the antimicrobial and cytotoxic activity showed different susceptibility towards the compounds tested. To understand these differential effects, a structureactivity relationship (SAR) study was carried out by analyzing the different chemical structure patterns of the evaluated compounds. Only phenolic acids (3\&4) showed activity, highlighting the importance of the carboxylic group in the molecule structure (proton acceptor). Furthermore, all the compounds with antimicrobial and cytotoxic activity have more $\mathrm{OH}$ (proton donor) as in compound 4 . In the compound $\mathbf{3}$ of less $\mathrm{OH}$ groups, the activity decreased. The presence of carboxylic acid and two hydroxyl groups in compound 4 seems to play an important role in the studied phenolic compounds antimicrobial and cytotoxic activity.

\section{CONCLUSION}

In this paper the isolation of new cytotoxic triterpenoids compounds, $2 \alpha$-hydorxy-3-oxo-lup12 (13), 20(29) diene-27,28dioic acid (3) and $2 \alpha, 27-$ dihydorxy-3-oxo-lup12 (13), 20(29) diene-28oic acid (4) is described, along with their biological evaluation in a number of cellular assays. The compounds 3 is more affect against Streptococcus pneumonia (S. pneumonia) and antimicrobial activity of compounds $\mathbf{4}$ is more affect than that of compounds 3 against Staphylococcus aureus ( $S$. aureus). The two new triterpenoids compounds $\mathbf{3}$ and $\mathbf{4}$ were moderately cytotoxic activity against the breast cancer and human colon carcinoma cells. In future research, we will be increase the potential cytotoxic activity by synthesis new derivatives of these isolated new compounds. 
Table 3. Cytotoxic activity of values of compounds $\mathbf{3}$ and $\mathbf{4}$

\begin{tabular}{|c|c|c|c|c|c|c|}
\hline \multirow{2}{*}{$\begin{array}{c}\text { Concentration } \\
\mu \mathrm{g} / \mathrm{ml}\end{array}$} & \multicolumn{3}{|c|}{$\%$ of inhibition cells } \\
\cline { 2 - 7 } & 3 & 4 & ${ }^{\mathrm{b}}$ Doxorubicin & 3 & \multicolumn{2}{c|}{ HCT-15 } \\
\cline { 2 - 7 } & $62.6 \pm 0.01$ & $62.6 \pm 0.01$ & $71.66 \pm 0.03$ & $65.6 \pm 0.01$ & $62.6 \pm 0.02$ & $72.62 \pm 0.03$ \\
\hline 5 & $52.6 \pm 0.02$ & $63.4 \pm 0.03$ & $79.87 \pm 0.02$ & $54.5 \pm 0.03$ & $64.4 \pm 0.03$ & $80.81 \pm 0.02$ \\
\hline 12.5 & $64.5 \pm 0.02$ & $64.5 \pm 0.02$ & $81.42 \pm 0.05$ & $80.5 \pm 0.02$ & $78.5 \pm 0.02$ & $82.12 \pm 0.02$ \\
\hline 25 & $79.6 \pm 0.02$ & $84.6 \pm 0.03$ & $86.90 \pm 0.06$ & $82.1 \pm 0.03$ & $81.3 \pm 0.03$ & $84.11 \pm 0.03$ \\
\hline 50 & 3.45 & 3.43 & 3.42 & 3.12 & 3.98 & 3.11 \\
\hline $\mathrm{IC}_{50}(\mu \mathrm{g} / \mathrm{ml})$ & & & & & & \\
\hline
\end{tabular}

Doxorubicin activities are expressed as IC50 values and those of compounds $\mathbf{3} \mathbf{8} \mathbf{4}$ are expressed as $\mathrm{IC}_{50}$ values in $\mu \mathrm{M}$. (-) IC50>100 $\mu$ M.

\section{ACKNOWLEDGMENTS}

Many thanks Greece, which enabled 9 months' study post doctor leave at the Lab. of organic chemistry, Natural product \& and natural product synthesis, Department of Chemistry, Faculty of science Aristotle University of Thessaloniki, Thessaloniki, Greece. We will also like to thank staff of Faculty of Sciences for the performance of some1D\&2D NMR\&MS spectral analyses experiments and many thanks for the staff of Faculty of Pharmaceutical Sciences for the performance of antimicrobial assay, as well as all of College of Science, Aristotle University of Thessaloniki, Thessaloniki, Greece, for providing bench space for this work is highly appreciated. The author wish to thank Egypt Government for funded and Zagazig University for financial support.

\section{REFERENCES}

1. V. Nour, I. Trandafir, M. E. Ionica, Notulae Botanicae HortiAgrobotanici Cluj-Napoc 38(3), 228, (2010).

2. S. A. Harris, B. E. Juniper, Plant Systematics and Evolution 226(1-2), $35,(2001)$.

3. P. L. Forsline, H. S. BAldwinckle, E. E. Dickson, J. J. Luby, S. C. Hokanson, Horticultural Reviews 29, 1,(2003).

4. Masucci, F. Nazzaro, The Open Food Science Journal 1, 10,(2007).

5. J. H. J. Martin, S. Crotty, P. Warren, P. N. Nelson, Phytochemistry 68(3), 266,(2007).

6. P. Keller, P. Sreker, G. Arnold, A. Schieber, R. Carle, Flussiges Obsterics 68, 48,(2001).

7. Y. Lu, Y. L. Foo, Food Chem. 68, 81,(2001).

8. M. Leontowicz, S. Gorinsten, H. Leontowicz, R. Krezeminski, A. Lojek, E. Katrich, M. C. R. Martin-Belloso, R. Solivafortuny, R. Haruenkit, S. Trakhtenberg, J. Agric. Food Chem. 51,5780, (2003).

9. J. Vinson, X. Su, L. Zubic, P. Bose, J. Agric. Food Chem. 49, 5315, (2001).

10. J. Sun, Y. Chu, X. Wu, L. R. .Hiu, J. Agric. Food Chem. 50,7449, (2002).

11. J. Boyer, R. H. Liu, Nutrition Journal 5, 1(2004).

12. R. S. A. Ismail, A. M. Bayomey, Egyptian Nutrition 25(2), 29, (2010).

13. X. He, R. H. Liu, Journal of Agricultural and Food Chemistry 55(11), 4366,(2007).

14. H. Yamaguchi, T. Noshita, Y. Kidachi, H. Umetsu, M. Hayashi, K. Komiyama, S. Funayama, K. Royayama, J. Health Sci. 54, 654, (2008).

15. S. Jäger, H. Trojan, T. Kopp, M. N. Laszczyk, A. SchefflerM, Molecules 14,2016, (2009).

16. J. H. Jorgensen, J. M. Swenson, F. C. Tenover, A. Barry, M. J. Ferraro, P. R. Murray, B. Reller, J. Clin. Microbiol. 34(11), 2679,(1996).

17. F. Ian, Culture of Animal Cells: a Manual of Basic Techniques; Fourth Ed.; New York: John, Wiley \& Sons, 1994, 330; 3

18. V. K. Tripathi, V. B. Pandey, K. N. Udupa, G. Rucker, Phytochemistry 31, 349,(1992)

19. S. P. Mahato, A. K. Kundu, Phytochem. 37(6), 1517, (1994).

20. F. R. Garcez, W. S. Garcez, D. L. S. Miguel, A. A. T. Serea, F. C. Prado, J. Braz. Chem. Soc. 14(3), 461,(2003).

21. M. Sholichin, K. Yamasaki, R. Kasai, O. Tanaka, Chem. Pharm. Bull. 28, $1006,(1980)$

22. W. Zimmermann, Hoppe-Seylers Z. Physiol. Chem. 300, 141,(1955).
23. R. H. Song, G. S. Li, Z. X. Zhang, J. Zhou, Act. Bota. Yunnan. 10,(1988). 24. C. Hsiao, D. Ying-Chi, L. Mei-Chin, L. An-Shen, H. Pei-Wen, W. ChinChung, C. Shu-Li, Y. Hsin-Fu, C. Fang-Rong, W. Yang-Chang, J. Nat. Prod. 71(8), 1352,(2008).

25. H. Safdar, R. Atta, M. I. Labal Choudhary, M. K. Khalid, L. Hamied, B. Ernst, Naturforsch 57(b), 233,(2002).

26. P. A. Elenga, S. Nikolov, D. Panova, Pharmazie 42,422,(1987).

27. S. Rita, M. R. Mohamed, M. T. James, F. Frank, A. R. Samir, J. Nat. Prod. 71, 2077-2079,(2008).

28. D. V. Singh, M. M. Gupta, A. K. Tripathi, V. Prajapati, S. Kumar, Phytother. Res. 18, 131,(2004).

29. Y. Lei, Y. Jing-Zhi, C. Xiao-Guang, S. Jian-Gong, Z. Dong-Ming, J. Nat. Prod. 72(5), 866,(2009). 